\title{
Effect of Compensation Towards Turnover Intention with Work Satisfaction as Intervening Variables a Study at PT. Madya Karya Putra
}

\author{
Dzulfiqar Mudhoffar Siregar ${ }^{1}$ Tri Maryati ${ }^{1, *}$
}

\author{
${ }^{1}$ Universitas Muhammadiyah Yogyakarta, Indonesia \\ *Corresponding author. Email: try_maryati@umy.ac.id
}

\begin{abstract}
This study aims to examine job satisfaction as a variable that mediates the relationship between compensation and turnover intention at PT. Madya Karya Putra. Compensation is something that must be considered by companies to increase the level of employee job satisfaction and reduce the desire to move employees at PT. Madya Karya Putra. Data analysis used path analysis with the number of respondents 48 people. The results showed that compensation had a positive and significant effect on job satisfaction. Compensation has a negative and significant effect on the desire to move employees. Job satisfaction has a negative and significant effect on the desire to move. Job satisfaction does not mediate the relationship between compensation and willingness to move.
\end{abstract}

Keywords: Compensation, Job Satisfaction, Desire to Move.

\section{INTRODUCTION}

In the millennial era as currently, in Indonesia continues to experience increases, one of which is the level of competition between companies or what is commonly referred to as business competition. In conditions of intense business competition, the organization seeks to retain employees or human resources owned by the organization.

The high turnover rate is not a problem that can be underestimated. You can imagine if the organization continues to lose employees, especially if it has taken the trouble to recruit quality employees, then it has been doing training and maybe having retrained so that the organization has trusted it. Still, it will lead to an employee's turnover intention to another company. But in fact, turnover often occurs in companies. This begins with the emergence of a desire to switch to another company or change jobs (turnover intention). Naman Shaman et al., (2016) in [1] stated that Turnover Intention is a person's behavioural attitude to leave a company, while turnover describes the actual act of separating oneself from a company.

Compensation is one of the factors that influence the desire to change jobs (turnover intention). Compensation itself is various forms of compensation that a company provides to its workers for the work that has been completed as stated by [2]. Apart from compensation, job satisfaction is also one of the factors that influence the desire to change jobs (turnover intention). According to [3], job satisfaction is a positive feeling about work, which results from an evaluation of its characteristics. According to Ilham Akhsanu (2012) in [4], the turnover rate is influenced by one's job satisfaction.

Currently, a company engaged in the contractor sector, namely PT. MADYA KARYA PUTRA has requests for work contracts with other companies such as hotels, malls, apartments, etc. make PT. MADYA KARYA PUTRA must be responsive in responding to these requests. This will certainly be an opportunity as well as a challenge for the company where the company must be able to maximize all employees in order to meet market demand. In order to maximize all employees, thus keeping employees from moving is the main thing in order to maximize the company's operational activities and to keep employees from moving, it is necessary to know the factors of compensation and employee job satisfaction. However, previous research that examined the effect of compensation and job satisfaction variables on the desire to move there is still confusion, one of which is as researched by [5] states that Job Satisfaction has a negative effect on Turnover Intention while research conducted by [6] states that Job satisfaction has a positive and significant effect on Turnover Intention. 


\section{LITERATURE REVIEW}

\section{Compensation}

According to [7], employee compensation includes all forms of payment given to employees and arises from their work relationship. According to [7], compensation is divided into 2, namely:

\section{Direct Financial Compensation}

Compensation can be in the form of salary, bonus, incentive.

\section{Indirect Financial Compensation:}

Indirect compensation is additional compensation provided under company policy to all employees in an effort to improve the welfare of employees-example, in the form of facilities, such as insurance, allowances.

\section{Job Satisfaction}

According to [3], job satisfaction is a positive feeling about work, which results from an evaluation of its characteristics. To measure job satisfaction, according to [3] is as follows: the job itself, salary, promotion, supervision, co-workers.

\section{Turnover Intention}

According to Widodo (2010) in [8] expressed turnover intention is in the form of a desire to find another job vacancy, evaluate the possibility of finding a better job elsewhere. According to Mobley et al. (1978) in [9] turnover intention is measured by four dimensions, namely: the tendency to leave the organization, the intention to seek or possibly find another job, the intention to quit or the possibility to leave the organization, the existence of better job alternatives.

\section{Effect Of Compensation On Job Satisfaction}

Rewards or remuneration provided by the company to its employees will affect an employee's satisfaction with his work. Then the higher the compensation was given, the more satisfied the employee feels for his job and conversely the lower the compensation given, the lower the employee's satisfaction with his job. This is in line with previous research conducted by [6], [4], [10], [11], [12], and [13] which states that compensation has a positive and significant effect on job satisfaction. Based on the logic of thinking and previous research, the following hypothesis can be derived:

H1: compensation has a positive and significant effect on job satisfaction

\section{Effect of Compensation On The Turnover Intention}

An employee who is completing his / her duties receives an adequate salary or compensation will not want to find another job because sufficient compensation is able to meet the employee's needs. So the higher the compensation was given, the lower the willingness to move employees and vice versa if an employee is given a little reward, the employee will tend to want to find another job that is deemed more feasible and better. This is in line with previous research conducted by [5], [14], [15], [1], and [16] which states that compensation has a negative and significant effect on Turnover Intention. Based on the logic of thinking and previous research, the following hypothesis can be derived:

$\mathrm{H} 2$ : Compensation has a negative and significant effect on Turnover Intention.

\section{The Effect of Job Satisfaction On Turnover Intention}

An employee who in his job feels that the job can meet his needs and can fulfil his wishes, the employees in the organization will not want to find another job because the job is able to meet the needs and desires of the employee. Then the higher the employee feels satisfied and their needs and wants are met, the lower the employee's desire to find another job is in line with previous research conducted by [9], [17], [18], [19], [20], [21], [8], [15], and [22], that state Job satisfaction has a negative and significant effect on turnover intention. Based on the logic of thinking and previous research, the following hypothesis can be derived:

H3: Job satisfaction has a negative and significant effect on Turnover Intention.

\section{The Effect of Compensation On The Turnover Intention With Job Satisfaction As An Intervening Variable}

The higher the compensation given to employees will make an employee have a high sense of satisfaction, with a high sense of satisfaction will reduce the level of employee desire to move to another company. Conversely, if the compensation was given is low or not in accordance with the job given it will make employees feel dissatisfied, with this dissatisfaction it will increase the level of willingness to move employees to another company which is expected to provide better rewards. This is in line with previous research conducted by [23] which states that job satisfaction mediates the effect of compensation on the intensity of employee turnover. Based on the logic of thinking and previous research, the following hypothesis can be derived:

H4: Compensation has an indirect effect on Turnover Intention through job satisfaction as an intervening variable. 


\section{RESEARCH METHODS}

\section{Research Objects and Subjects}

The object of this research is PT. MADYA KARYA PUTRA, located on Jl. Ledok Gondomanan No.6, Prawirodirjan, Gondomanan, Yogyakarta. Then for the subjects in this study are employees who work at PT. MADYA KARYA PUTRA.

\section{Data and Data Collection Techniques}

The type of data used in this study is primary data. The research method that will be used by researchers is to use a questionnaire containing a statement.

\section{Population and Sample}

According to [24] Population is the entire group of people or the whole object being observed and the sample is a part of the population. In this case, the population is all employees who work at PT. MADYA KARYA PUTRA. Researchers used a census-taking method, namely using the entire population of 48 permanent employees as research respondents.

\section{Operational Definition of Variables}

\section{Job Satisfaction}

Job satisfaction is a positive sense of the job resulting from the evaluation of its characteristics [3].

\section{Turnover Intention}

Mobley et al. (1978) in [25] turnover intention is the result of an individual's evaluation of the continuation of his relationship with the company where he works but has not yet manifested himself in definite action leaving the organization.

\section{Compensation}

According to Simamora (2004) in [26], compensation includes financial benefits and intangible services as well as benefits received by employees as part of the employment relationship.

\section{Instrument Quality Test}

The data testing method is intended to test descriptive statistical analysis, test the validity and reliability of the questionnaires used in the study so that it can be seen to what extent the questionnaire can be a valid and stable measuring tool in measuring data.

\section{Classic Assumption Test}

Heteroscedasticity Test: The heteroscedasticity test aims to test whether the regression model has inequality of variance from one residual to another observation. If the variance of the residuals from one observation to another is constant, it is called Homoscedasticity, and if it differs, it is called heteroscedasticity. A good regression model is heterocedasticity, or heteroscedasticity does not occur.

Normality Test: Normality test aims to test whether in the regression model confounding or residual variables have a normal distribution. Regression models that either has normal or near-normal data distributions. This study used the normality test with the Kolmogorov-Smirnov (KS) non-parametric statistical test. A variable is said to be normally distributed if its significance value is greater than alpha 0.05 [27]. The normality test was carried out twice, namely the first and second regressions.

Multicollinearity Test: Multicollinearity test aims to test whether the regression model found a correlation between the independent variables (independent). A good regression model should not have a correlation between the independent variables. To detect the presence or absence of multicollinearity in the regression model is to look at the tolerance value and variance inflation factor [27]. The way to test for multicollinearity symptoms is to look at the tolerance value and variance inflation factor (VIF). If the VIF value is below 10, the regression model does not have multicollinearity symptoms, and vice versa if the VIF value is above 10 , the regression model has multicollinearity symptoms. And by looking at the tolerance value less than 0.10 indicates multicollinearity.

\section{RESULTS AND DISCUSSION}

\section{Result}

\section{Simple Linear Regression Analysis}

Simple linear regression analysis is used to examine the effect of the compensation variable on job satisfaction.

Table 1. The result of a simple linear regression analysis of the compensation variable on the job satisfaction variable

\begin{tabular}{|l|l|l|l|l|l|l|}
\hline Variable & B & Std. Error & Beta & Don't count & sig & Information \\
\hline (Constant) & 8,702 & & & & & \\
\hline Compensation & 0.598 & 0.088 & 0.707 & 6,780 & 0.000 & Significant \\
\hline$R$ Square & 0.489 & & & & & \\
\hline
\end{tabular}


Based on table 6 , it is obtained that the sig value is $0.000<0.05$ so that the compensation variable has a positive and significant effect on job satisfaction. The beta coefficient is positive 0.707 , meaning that the higher the compensation will increase job satisfaction.

\section{Multiple Linear Regression Analysis}

Multiple linear regression analysis was used to examine the effect of compensation and job satisfaction variables on the desire to move employees.

Table 2. Results of Compensation Multiple Linear Regression Analysis, Job Satisfaction Against the Desire to Move

\begin{tabular}{|l|l|l|l|l|l|l|}
\hline Variable & $\begin{array}{c}\text { Std. } \\
\text { Error }\end{array}$ & Beta & $\begin{array}{l}\text { Don't } \\
\text { count }\end{array}$ & Sig t & Information & Information \\
\hline (Constant $)$ & & & & & & \\
\hline Compensation & 0.154 & -0.348 & $-2,154$ & 0.037 & significant & Significant \\
\hline Job satisfaction & 0.183 & -0.348 & $-2,157$ & 0.036 & significant & \\
\hline
\end{tabular}

\section{Effect Of Compensation On Turnover Intention}

Based on table 2, the t-count value is obtained $-2,154$ regression coefficient (Beta) -0.348 with probability (p) $=0.037$. Based on the results of data processing, where The probability value $(p)>0.05$ can be concluded that compensation has a negative and significant effect on the intention to move. This shows that the higher the compensation, the lower the desire to change employees.

\section{The Effect Of Job Satisfaction On Turnover} Intention
Based on the table above, the t-count value is obtained -2,157 regression coefficient (Beta) -0.348 with probability $(p)=0.036$. Based on the results of data processing where the probability value $(p)<0.05$, it can be concluded that job satisfaction has a negative and significant effect on employee performance. This shows that increasing job satisfaction can reduce the desire to change employees significantly.

\section{Path Analysis and the Sobel Test}

Path Analysis and Sobel test are used to test the job satisfaction variable as an intervening variable.

Table 3. Result of path analysis variable compensation, job satisfaction and desire to move

\begin{tabular}{|l|}
\hline Direct Effect \\
\hline $\mathrm{X}($ Compensation $) \rightarrow \mathrm{Y}$ (Turnover Intention) \\
\hline$=-0,348$ \\
\hline Indirect Effect \\
\hline $\mathrm{X}($ Compensation $) \rightarrow \mathrm{Z}($ job satisfaction $) \rightarrow \mathrm{Y}($ Turnover Intention $)$ \\
\hline $0.707 \mathrm{X}-0,348=-0.246036$ \\
\hline Total Effect \\
\hline Direct Effect + Indirect Effect $=-0,348+(-0,246036)=-0.594036$ \\
\hline
\end{tabular}

Based on Table 3, it can be seen that compensation has an indirect effect on Turnover Intention through job satisfaction of -0.246036 . The direct effect is obtained by- 0,348 so that the total effect is equal to -0.594036 . Because the results of the direct effect are more significant than the indirect effects, the job satisfaction variable does not mediate the effect of compensation on turnover intention.

\section{Sobel Test}

Sobel test results in variable compensation, job satisfaction and turn over intention

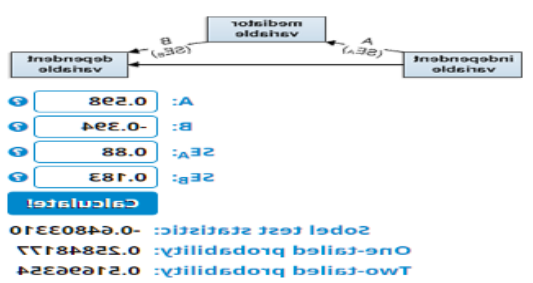

From the calculation of the Sobel test, the mediation value of the job satisfaction variable is -0.648 . The variable is said to mediate if the value obtained through the Sobel test is greater than 1.98. The results of this study job satisfaction have a mediating value of -0.648 which means it is smaller than 1.98. So job satisfaction does not mediate the effect of compensation on turnover intention.

\section{Discussion}

\section{Effect Of Compensation On Job Satisfaction}

In testing hypothesis 1 in this study, the results of the data prove that there is a significant positive effect between compensation on job satisfaction which indicates that hypothesis 1 is accepted. Then the higher the compensation was given, the more satisfied the employee feels for his job and conversely the lower the compensation given, the lower the employee's 
satisfaction with his job. The compensation given to the employees of PT Madya Karya is considered sufficient and makes the employees feel satisfied with their work. The compensation was given by PT. Madya Karya Putra includes salary, overtime pay, etc.

\section{Effect Of Compensation On Turnover Intention}

In testing hypothesis 2 in this study proves that there is a significant negative effect between compensation on turnover intention, which shows that the hypothesis that compensation has a negative and significant effect on job satisfaction is accepted. Employees of PT. Madya Karya Putra is satisfied with the compensation provided by the company such as salary, overtime pay, etc. The compensation provided by the company makes employees feel comfortable and do not want to leave the company. This shows that the higher the compensation was given to employees, the lower the employee's desire to leave the company.

\section{Effect Of Job Satisfaction On Turnover Intention.}

In testing hypothesis 3 in this study proves that there is a significant negative effect between job satisfaction on turnover intention, which shows that the hypothesis that job satisfaction has a negative and significant effect on turnover intention is accepted. From these results, it can be seen that the employees of PT. Madya Karya Putra is reluctant to leave the company because he is satisfied with his job and vice versa if they are not satisfied, they will think and then move to a workplace that is more satisfying.

\section{Effect Of Compensation On Turnover Intention With Job Satisfaction As An Intervening Variable.}

The results of the data show that job satisfaction does not mediate the effect of compensation on turnover intention. This can be seen in the hypothesis test 4 , where the value of the direct effect is greater than the indirect effect. This concludes that job satisfaction does not mediate compensation for turnover intention. So the hypothesis which states that there is an effect of compensation on turnover intention with job satisfaction as an intervening variable is rejected. The direct effect test results prove that the effect of compensation shows a significant negative impact on turnover intention. This could prove that they could be employees of PT. Madya Karya Putra considers that compensation is more closely related to the desire to move than satisfaction at work, or it can be said that employees are more concerned with compensation for working at PT.

\section{CONCLUSION}

Based on the results of data analysis through direct distribution of questioner to employees of PT. Madya Karya Putra and hypothesis testing that has been done, it can be concluded that:
1. Compensation has a positive and significant effect on job satisfaction

2. Compensation has a negative and significant effect on turnover intention

3. Job satisfaction has a negative and significant effect on turnover intention

4. Job satisfaction cannot mediate the effect of compensation on turnover intention

The implication of this research result is that PT. Madya Karya Putra needs special attention to employees. Compensation given to employees needs to be considered because this will have an impact on the desire of employees to leave the company. Besides that, it is also necessary to pay attention to employee job satisfaction so that employees can feel at home with their work and do not think about leaving the company.

\section{REFERENCES}

[1] Meilano, MR, \& Nugraheni, R. (2017). Analisis Pengaruh Lingkungan Kerja Dan Kompensasi Terhadap Turnover Intention Dengan Kepuasan Kerja Sebagai Variabel Intervening (Studi Pada Karyawan Laksana Baru Swalayan Majenang). Diponegoro Journal Of Management

[2] Ulfatin, N., \& Triwiyanto, T. (2016). Manajemen Sumber Daya Manusia Bidang Pendidikan. Jakarta. Jakarta: Rajawali Press

[3] Robbin, SP, \& Judge, TA (2016). Organizational Behaviour. Jakarta: Four Salemba

[4] Indra Nugraha, MB, \& Surya, IBK (2016). Pengaruh Kompensasi, Lingkungan Kerja dan Promosi Jabatan terhadap Kepuasan Kerja. E-Jurnal Manajemen Universitas Udayana, 5(1).

[5] Pranowo, RS (2016). engaruh Kepuasan Kerja, Lingkungan Kerja, Dan Kompensasi Terhadap Turnover Intention Karyawan Dengan Lama Kerja Sebagai Variabel Pemoderasi (Studi Kasus Pada Cv. Sukses Sejati Computama). Jurnal Profita: Kajian Ilmu Akuntansi, 4(4)

[6] Ayesha. Y. (2013). Effect of Compensation Factors on Employee Satisfaction- A Study of Doctor"s Dissatisfaction in Punjab. International Journal of Human Resource Studies. ISSN 2162-3058. 2013, Vol. 3, No. 1, 142-157.

[7] Dessler, G. (2015). Manajemen Sumber Daya Manusia. Jakarta: Salemba Empat

[8] Putri, A., \& Rumangkit, S. (2017). Pengaruh Ketidakamanan Kerja, Kepuasan Kerja Dan Motivasi Kerja Terhadap Turnover Intention Pada Pt.Ratu Pola Bumi (Rpb) Bandar Lampung. 
Prosiding Seminar Nasional Darmajaya, 1(1), 229244.

[9] Alam. A.\& Asim.M. (2019). Relationship Between Job Satisfaction and Turnover Intention. International Journal of Human Resource Studies ISSN 2162-3058 . 2019, Vol. 9, No. 2, 163-194.

[10] Salisu, JB, Chinyio, E., \& Suresh, S. (2015). The impact of compensation on the job satisfaction of public sector construction workers of Jigawa state of Nigeria. 6 (4), 15.

[11] Srimindarti, C., Oktaviani, RM, \& Hardiningsih, P. (2017). Antecedents of Job Satisfaction and the Influence on Turnover Intention. Journal of Management Dynamics, 8 (2), 177-187. https://doi.org/10.15294/jdm.v8i2.12758

[12] Fauzi, I.-. (2017). Pengaruh Ketidakamanan Kerja, Komitmen Organisasional dan Kepercayaan Organisasional pada Keinginan Berpindah. Management Analysis Journal, 5(1).

[13] Nurcahyani, NM, \& Adnyani, IGAD (2016). Pengaruh Kompensasi dan Motivasi terhadap Kinerja Karyawan dengan Kepuasan Kerja sebagai Variabel Intervening. E-Jurnal Manajemen Universitas Udayana, 5(1).

[14] Parashakti, RD, Nashar, M., \& Usliawati, D. (2017, July). The Effect of Compensation and Organization Commitment towards Turnover Intention. Case Study in ILC (International Language Center) Jakarta. Presented at the 2017 International Conference on Organizational Innovation (ICOI 2017).

[15] Khaidir, M., Bachri, AA, \& Sugiati, T. (2017). Pengaruh Stres Kerja, Kompensasi Dan Kepuasan Kerja Terhadap Turnover Intention Studi Pada Karyawan Kontrak Pt. Gagah Satria Manunggal Banjarmasin. Jurnal Wawasan Manajemen, 4(3), 175-186.

[16] Candra, DM, Hana, SWL, \& Wulandari, D. (2018). Compensation And Turnover Intention In Coal Mining Support Companies In South Kalimantan. International Journal of Scientific \& Technology Research, 7 (4), 202-205.

[17] Nazenin, S., \& Palupiningdyah. (2014). Peran Stres Kerja dan Kepuasan Kerja untuk Mengurangi Turnover Intention.

[18] Halimah, TN, Fathoni, A., \& Minarsih, M. (2016). Pengaruh Job Insecurity, Kepuasan Kerja dan Lingkungan Kerja terhadap Turnover Intention Pramuniaga di Gelael Supermarket (Studi Kasus Pada Gelael Superindo Kota Semarang). Journal of Management.
[19] Putra, DE, \& Ketut Surya, I. (2016). Pengaruh Kepuasan Gaji terhadap Turonver Intention dengan Komitmen Organisasional sebagai Mediasi pada Rumah Sakit Umum Premagana.

[20] Ridho, S., \& Syamsuri, AR (2018). Analisis Pengaruh Job Insecurity Dengan Kepuasan Kerja Dan Komitmen Organisasi Sebagai Variabel Intervening Terhadap Intensi Turnover. Jurnal Ilmiah Amik Labuhan Batu.

[21] Rismayanti, R., Al Musadieq, M., \& Aini, E. (2018). Pengaruh Kepuasan Kerja terhadap Turnover Intention serta Dampaknya pada Kinerja Karyawan (Studi pada Karyawan Tetap PG Kebon Agung Malang).Jurnal Administrasi Bisnis (JAB).

[22] Prabawa, MY, \& Suwandana, IGM (2017). Pengaruh Ketidakamanan Kerja, Kepuasan Kerja dan Komitmen Organisasional terhadap Turnover Intention pada Grand Mirage Resort \& Thalasso Bali. E-Jurnal Manajemen Universitas Udayana, $6(12)$.

[23] Rohmawati, I., Yulianeu, Y., Wulan, HS, \& Paramita, PD (2017). pengaruh gaya kepemimpinan transformasional dan kompensasi terhadap intensitas turnover yang dimediasi kepuasan kerja (Studi Pada Karyawan Bagian Sewing PT Maxmoda Indo Global). Journal of Management, 3 (3).

[24] Sekaran, U. \& Bougie, R. (2017). Metode Penelitian untuk Bisnis. Jakarta: 4 Salemba

[25] Yin-Fah, B., Sook Foon, Y., Lim, C.-L., \& Syuhaily, O. (2010). An Exploratory Study on Turnover Intention among Private Sector Employees. International Journal of Business and Management, 5.

[26] Nawa, F. \& Kempa, S. (2017). Pengaruh Kompensasi dan Disiplin Kerja terhadap Kinerja Karyawan pada PT. Pln (Persero) Wilayah Nusa Tenggara Timur. Agora, 5(2).

[27] Ghozali, I. (2011). Aplikasi Analisis Multivariate dengan Program SPSS. Semarang: Badan Penerbit Universitas Diponegoro. 